\title{
Phytochemical Analysis of Methanolic Extract of Jordanian Melissa officinalis L.
}

\author{
Hammad K. Aldal'in ${ }^{1}$ \\ ${ }^{1}$ Department of Medical Support, Al-Balqa Applied University, Al-Karak University College, Al-Karak, Jordan \\ Correspondence: Hammad K. Aldal'in, Department of Medical Support, Al-Balqa Applied University, Al-Karak \\ University College, Al-Karak, Jordan. E-mail: hammadhammad1977@yahoo.com
}

Received: September 10, 2018

Accepted: September 22, $2018 \quad$ Online Published: September 28, 2018

doi:10.5539/ijb.v10n4p58

URL: https://doi.org/10.5539/ijb.v10n4p58

\begin{abstract}
The methanolic extract obtained from leaves, steam and seeds of $M$. officinalis growing in Karak city-Jordan, was investigated, discussed for its phytoconstituents for the first time and analyzed by GC-MS instrument with BSTFA and Heptan solvents. Plant parts were collected during the spring semester 2018. Results showed that leaves extract have twenty one major and minor natural compounds available in all parts. Six of them which were above 1 $\%$ have been found in the extract of leaves more than other parts of the plant. Leaves extract are a good source of various phytoconstituents. These natural compounds gave leaves an important role to use it as anticancer and sedative due to the presence of Palmitic acid and polar compounds. Leaves are much interesting part due to the availability of these bioactive compounds as major and minor compounds more than other parts. Thus, the isolation of leaves phytochemical compounds will give fruitful results for further detailed study.
\end{abstract}

Keywords: M. officinalis, GC-MS, phytocomponents, Jordan, Palmitic acid

\section{Introduction}

In recent years, fruits and plants are classified as an important source of main active biologically compounds. There are $85-90 \%$ of the world's populations use plants as traditional herbal medicines according to the World Health Organization (WHO) reports (Selvamangai \& Bhaskar, 2012).

Many people in Jordan use traditional medicinal plants as additional, alternative or complementary medicine (Aldal'in, 2018). However, most of them haven't detailed phytochemical and main biologically active compounds. One of these plants is called Jordanian Melissa (Al-Khalil, 1995). Melissa officinalis L. (M. officinalis) is a member of the Lamiaceae family, known as Lemon balm. It is distributed and commonly in Mediterranean region and western Asia. This plant is cultivated in Jordan and largely used as an important folk medicinal plant species (Schultze et al., 1993). Melissa has been traditionally used for the treatment of different medical purpose as tonic, colic, depression, nervousness and stress induced headaches (Beloued, 2009), antiseptic, calmative (Baytop, 1984), antimicrobial effect against Gram positive and Gram negative bacteria (Vitullo et al., 2011, Larrando et al., 1995), antifungi (Abdellatif et al., 2014). Furthermore, it can be used as antitumor activity (Galasinski, 1996), anti-HIV activity (Yamasaki et al., 1998), antiviral (Adorjan and Buchbauer, 2010), antidiabetic activity (Chung et al., 2010). M. officinalis has been reported that contain natural products that can inhibits protein biosynthesis in the cancer cells (Adorjan and Buchbauer, 2010). It has been also found that M. officinalis has stronger than vitamins B and C as antioxidant effects (Ghayoor et al., 2010). The bioactivity of $M$. officinalis refers to contain phenolic acids such as rosmarinic acid and caffeic acids (Constantine, 2007; Tagashira \& Ohtake, 1998) and flavonoids (Ziakova et al., 2003). Triterpene (Mencherini et al., 2007) and phenylpropanoid heteroside was reported (Mulkens \& Kapetanidis, 1988). Moreover, it was also found to treat externally such as gout, herpes, and sores, insect repellent (Bown, 1995).

The methanolic extract and volatile oils of aerial parts of Jordanian M. officinalis from Wadi Rujb-Ajlun were showed anti-proliferation effects against two types of colorectal (SW480), (HCT116), and prostate (PC3) cancer cell lines (Barakat et al., 2016).

The comparison of chemical composition of methanolic extract of leaves stems and seeds of Jordanian $M$. officinalis by GC/Ms haven't been investigated. Moreover, the contents of natural products of M. officinalis may vary based on the location. Therefore, the aim of this paper is to analyze and compare the chemical composition of 
methanolic extract of all parts of $M$. officinalis from Karak-Jordan by GC/MS method, and to investigate the most important part that contains the important phytoconstituents.

\section{Material and Methods}

\subsection{Collection of the Plant Materials}

Fresh leaves, stems and seeds of wild growing M. officinalis plants were collected from Karak governorate-Jordan in the beginning of spring semester 2018. M. officinalis was identified according to Al-Eisawi (Al-Eisawi, 1998). All parts of $M$. officinalis were shade dried and separated at room temperature until reached constant weight, pulverized and stored in the dark place.

\subsection{Extraction Process}

One gram of each cleaned and dried leaves, stems and seeds of M. officinalis was soaked and extracted with $10 \mathrm{ml}$ of methanol and continuous shaking at room temperature for 4 days. The filtrate of each part was centrifuged at $4500 \mathrm{rpm}$ for 10 minutes. After that, $3.0 \mathrm{ml}$ of each supernatant was transferred to $10 \mathrm{ml}$ test tube and evaporated at room temperature. The residues were reconstituted with $100 \mu 1$ of Heptan and BSTFA derivatization solution and inject in GC/MS.

\subsection{Gas Chromatography-Mass Spectrometry (GC-MS) Analysis}

GC/MS analysis was carried out on a Agilent technology type $6890 \mathrm{GC}$ equipped with Split-splitless injector and capillary column type of HP-5MS coated with a film $5 \%$ of phenylmethylpolysiloxane $(30 \mathrm{~m} \times 0.25 \mathrm{~mm}, 0.25 \mu \mathrm{m}$ film thickness). This agilent number $6890 \mathrm{GC}$ is equipped with a mass spectrometer type of 5973C Inert MSD (Mass Spec, Mass Spectrometer, Mass Selective Detector, MS, and GC/MS). The temperature of column oven was programmed as follows: beginning temperature is $60^{\circ} \mathrm{C}$, increased to $300^{\circ} \mathrm{C}$ with a ramp of $15{ }^{\circ} \mathrm{C} / \mathrm{min}$, the temperature was held to $300^{\circ} \mathrm{C}$ for 7 min until all of elution was completed. The split valves were opened for 3 minutes after 15 seconds to purge the injector. All injections $(1 \mu \mathrm{L})$ were made with a $10 \mu \mathrm{L}$ syringe. Helium gas was used with purity of $99.999 \%$, as the carrier gas at a flow rate of $1.0 \mathrm{ml} / \mathrm{min}$ (krafczyk \& Glomb, 2008).

\section{Results}

The modern GC-MS instrument has been used with a certain conditions as described above to evaluate quantitatively and qualitatively the constituents in the methanolic crude extract of each parts of the plant. Herein, MS analyzer (quadrupole) was connected with computer data analysis software with National Institute of Standards Technology (NIST08s) mass spectral library. In Figure 1, all peaks in the resulting chromatograms in Heptan and BSTFA with retention times and the fragmentation pattererns for all parts of the plant were compared with published literatures and the standard library NIST08s.

The comparison of GC-MS chromatograms of Heptan and BSTFA of the methanolic extract of leaves, stems and seeds of M. officinalis are described for the first time. The GC-MS results in BSTFA have been found many derivatives as polar and nonpolar constituents in all parts with different percent while in Heptan had very little effect to describe the phytoconstituents. Extract of leaves, stems, and seeds of M. officinalis chemical compositions in two solvents were analyzed by GC-MS and the results are shown in Table 1.
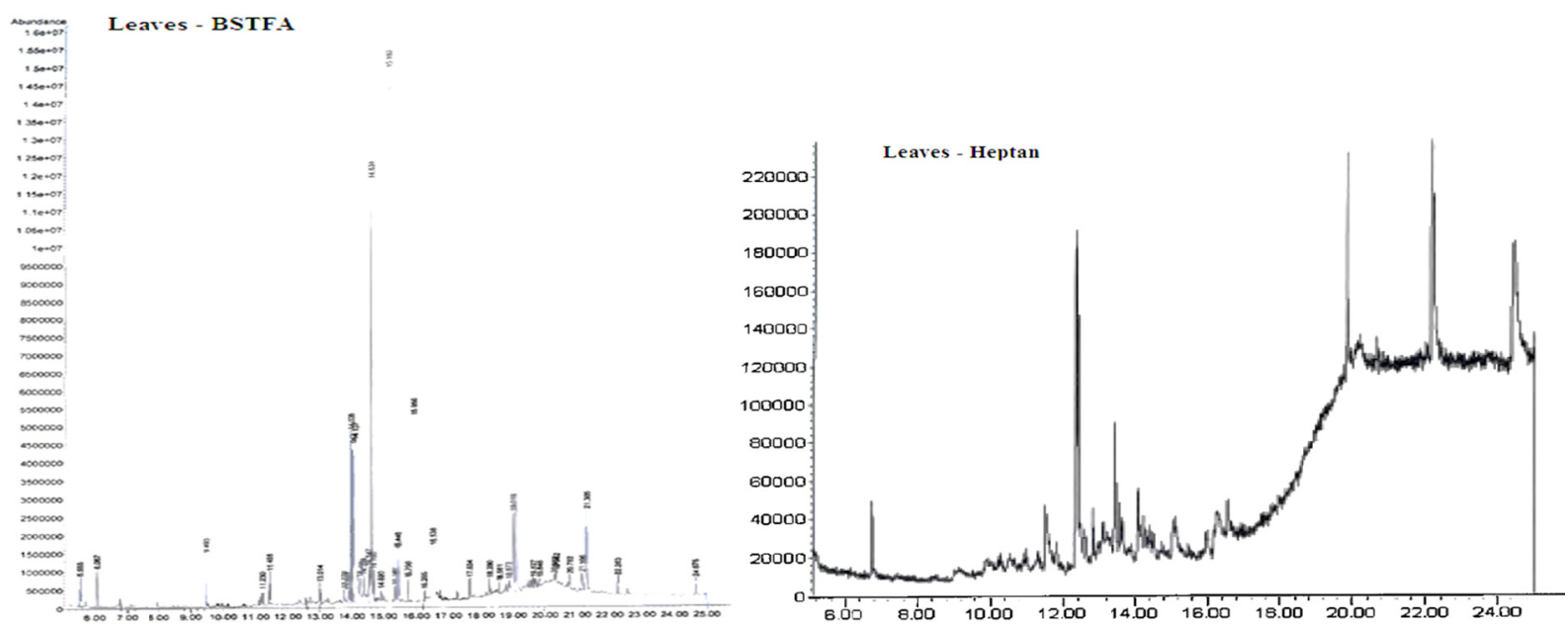

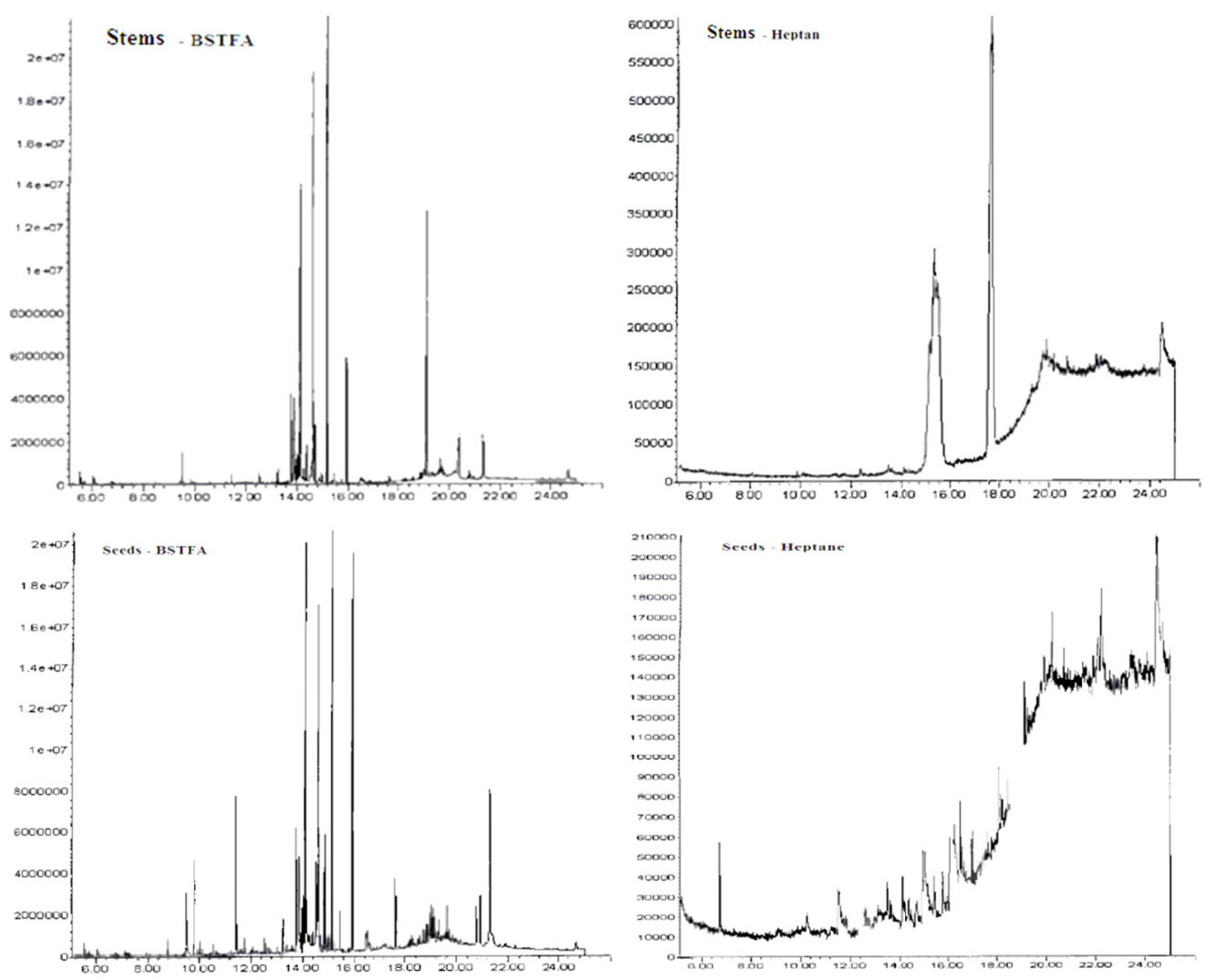

Figure 2. GC/MS chromatograms of methanolic extract of leaves, stems and seeds of M. officinalis in Heptan and BSTFA

Table 1. Comparison the phytocomponents identified in the methanolic extracts of M. officinalis (leaves, stems and seeds) by GC-MS with Heptan and BSTFA

\begin{tabular}{|c|c|c|c|c|c|c|c|c|}
\hline \multirow{2}{*}{ Compounds } & \multirow{2}{*}{ RT } & \multicolumn{3}{|c|}{$\%$ Compound by BSTFA } & \multirow{2}{*}{ RT } & \multicolumn{3}{|c|}{ \% Compound by Heptan } \\
\hline & & Leaves & Stem & Seeds & & Leaves & Stem & Seeds \\
\hline Ethylamine & 5.55 & 0.68 & 0.01 & 0.05 & ---- & --- & -- & -- \\
\hline Cyanuric Acid & 6.06 & 1.52 & 0.02 & 0.04 & --- & --- & --- & --- \\
\hline 1,3-Propanediol & 9.49 & 0.76 & 0.09 & 0.02 & 9.88 & -- & 0.03 & 0.03 \\
\hline Androstan-3-one & 11.23 & 0.36 & 0.05 & 0.01 & --- & --- & --- & --- \\
\hline Malic Acid & 11.45 & 0.65 & 0.04 & 0.05 & --- & --- & --- & --- \\
\hline N-Butyrlglycine & 13.01 & 0.33 & 0.03 & 0.01 & --- & --- & --- & --- \\
\hline Ascrobic Acid & 14.26 & 0.57 & 0.07 & 0.09 & --- & --- & --- & -- \\
\hline Undodecenedioic Acid & 14.69 & 0.53 & 0.02 & 0.04 & 15.08 & 0.12 & 0.03 & 0.44 \\
\hline 3-OH-Tetradecenedioic Acid & 14.63 & 8.21 & 0.15 & 0.13 & --- & --- & --- & --- \\
\hline 3-OH-Dodecenedioic Acid & 15.18 & 9.87 & 0.14 & 0.14 & 15.377 & --- & 0.12 & --- \\
\hline Palmitic Acid & 15.45 & 0.63 & 0.03 & 0.08 & 15.466 & -- & --- & 0.11 \\
\hline Glucuronic-1-Pent & 15.95 & 2.19 & 0.02 & 0.07 & 16.27 & 0.13 & --- & 0.02 \\
\hline Silane & 16.26 & 0.29 & 0.01 & 0.08 & 16.27 & --- & --- & 0.01 \\
\hline Isobutyric & 16.53 & 0.91 & 0.03 & 0.06 & 16.23 & -- & --- & 0.06 \\
\hline phenobarbitol & 19.01 & 1.54 & 0.05 & 0.05 & 18737 & --- & 0.02 & --- \\
\hline$\alpha$ - D-Glucopyranose & 19.10 & 9.36 & 0.07 & 0.02 & --- & -- & --- & -- \\
\hline D-Glucose & 20.30 & 0.55 & 0.02 & 0.01 & --- & --- & --- & -- \\
\hline Melibiose & 20.36 & 0.50 & 0.02 & 0.01 & --- & --- & -- & --- \\
\hline Maltose & 21.16 & 0.47 & 0.01 & 0.06 & --- & --- & --- & --- \\
\hline$\alpha$ - Tocopherol & 22.26 & 0.75 & 0.05 & 0.02 & --- & --- & --- & -- \\
\hline$\beta$ - Sitosterol & 24.68 & 0.26 & 0.02 & 0.02 & --- & --- & --- & --- \\
\hline
\end{tabular}




\section{Discussions}

Heptan and N,O-bis(trimethylsilyl)trifluoroacetamide (BSTFA) derivatization solution were used as a nonpolar and polar solvents in GC/MS analysis, respectively. The GC-MS outputs can be analyzed to get a good information about nonpolar (fatty acids, hydrocarbons) and polar functionalities such aromatic and aliphatic alcohols, carbonyl compounds and carbohydrates. Furthermore, BSTFA derivatization can be used to improve peak shape of natural compounds by reducing tailing and this will lead to characterize unknown ketones, alcohols, and fatty acids by GC-MS (Stalling et al., 19968).

The GC-MS chromatograms of methanolic extract of M. officinalis showed twenty one major peaks available in all parts. The analysis of these peaks described that leaves have the highest contents in BSTFA of different natural products. All peaks were identified by comparing their mass with NIST08s library.

A later step of the present work was to find the phytoconstituents by using GC-MS analyses, where the composition of $M$. officinalis contributes significantly to the biological effects (Bakkali et al., 2008). From table 1, it was noticed that six components of which were above $1 \%$ have been found in the extract of leaves. These compounds Cyanuric Acid 1.52\%, 3-OH-Tetradecenedioic Acid 8.21\%, 3-OH-Dodecenedioic Acid 9.87\%, Glucuronic-1-Pent $2.19 \%$, phenobarbitol $1.54 \%$ and $\alpha$ - D-Glucopyranose $9.36 \%$ were found as major compounds with the highest percentage than others. Otherwise, the extract of leaves was found also rich in the minor compounds compared with other parts of the plant.

The leaves content have several uses such as Palmitic acid which was reported as antimicrobial effects, cytotoxicity against MCF-7, WRL-68, CaCo2, and Colo-320 cancer cell lines, it can possess significantly hepatoprotection against galactosamine and cholesterolaemic (French, 2002; Barbara, 2002). Furthermore, most of these contents have traditionally been gave $M$. officinalis a memory enhancing properties and it is widely used as a sedative (Kennedy et al., 2004).

\section{Conclusion}

GC-MS analysis of methanolic extract of leaves, stems, and seeds of M. officinalis showed the presence of several of the important components like Fatty acids, polar compounds and their biological activities. The extract of leaves is much interesting due to having highest contents of major and minor natural compounds than other parts of the plant. These results are the first step to understand the nature of active ingredient in this medicinal plant. Thus, the presence study will be helpful for further detailed work.

\section{Conflict of interests}

The author claim that there is no conflict of interest

\section{References}

Abdellatif, F., Boudjella, H., Zitouni, A., \& Hassani, A. (2014). Chemical composition and antimicrobial activity of the essential oil from leaves of Algrian Melissa Officinalis L. EXCLI J., 13, 772-81.

Adjorjan, B., \& Buchbauer, G. (2010). Biological properties of essential oils: an apdated review. Flav. Fragr. J., 25, 407-26. https://doi.org/10.1002/ffj.2024.

Aldal'in, H. (2018). Chemical composition of the methanolic extract from seeds, thorns and leaves of Sarcopoterium spinosum (L.) (Rosaceae) grown in Al-Tafila, Jordan. Res. on Crops, 19(2), 315-19. https://doi.org/10.5958/2348-7542.2018.00048.7

Al-Eisawi, D. M. (1998). Field Guide to Wild Flowers of Jordan and Neighbouring Countries. Press-Foundation Al-Rai, Jordan.

Al-Khalil, S. (1995). A survey of plants used in Jordanian traditional medicine. Int. J. of Pharmacog, 33, 317-23. https://doi.org/10.3109/13880209509065385

Bakkali, F., Averbeck, S., Averbeck, D., \& Idaomar, M. (2008). Biological effects of essential oils. Rev. Food Chem. Toxicol., 46, 446-75. http://dx.doi.org/10.1016/j.fct.2007.09.106.

Barakat, S., Hudaib, M., El-Asad, N., \& Burns, D. (2016). Composition of Volatile Oil and Methanolic Extract of Jordanian Melissa Officinalis L. and actions against Human Cancer Cell Lines. Orient. J. Chem., 32(5), 2355-62. http://dx.doi.org/10.13005/ojc/320506

Barbara, Y., Kerry, L., Maureen, T., \& Erasmus, D. G. (2002). The pharmacological Screening of Pentanisia prunelloides and the isolation of the antibacterial compound Palmitic acid. J. Ethanopharmacology, 79, 101-7. http://dx.doi.org/10.1016/S0378-8741(01)00380-4 
Baytop, T. (1984). Turkiye'de Bitkilerle Tedavi (No. 3255). Istanbul Universitesi Yayınları, Istanbul.

Beloued, A. (2009). Plantes médicinales d'Algérie (p. 134). Alger: Office des Publications Universitaires.

Bown, D. (1995). Encyclopaedia of Herbs and their Uses. London: Dorling Kindersley.

Chung, M. J., Cho, S. Y., Bhuiyan, M. J. H., Kim, K. H., \& Lee, S. J. (2010). Anti-diabetic effects of lemon balm (Melissa officcinalis) essential oil on glucose and lipid regulating enzymes in type 2 diabetic mice. Brit. $J$. Nutr., 104, 180-8. http://dx.doi.org/10.1017/S0007114510001765

Constantine, D. S. (2007). Extraction, separation and detection methods for phenolic acids and flavonoids. J. Sep. Sci., 30, 3268-95.http://dx.doi.org/ 10.1002/jssc.200700261

French, A. M., Sundram, K., \& Thomas, C. M. (2002). Cholesterolaemic effect of palmitic acid in relation to other dietary fatty acid. Asia Pacif. J. Clin. Nutr., 11, S401-S407.

Galasinski, W. (1996). Eukaryotic polypeptide elongation system and its sensitivity to the inhibitory substances of plant origin. Proc. Soc. Exp. Biol. Med., 212, 24-37. https://doi.org/10.3181/00379727-212-43988

Ghayoor, N., Rasouli, B., \& Afsharian, M. (2010). The protective effects of Melissa officinalis leaves usage on learning disorder induced by lead acetate administration during pre and postnatal periods in rats. Persian. Arak. Med. Univ. J., 13(1), 97-104.

Krafczyk, N., \& Glomb, M. A. (2008). Characterization of phenolic compounds in rooibos tea. J. Agric. Food Chem., 56(9), 3368-76. http://dx.doi.org/10.1021/jf703701n

Kennedy, D. O., Little, W., \& Scoley, A. B. (2004). Attenuation of laboratory - induced stress in humans after acute administration of M. officinalis (Lemon balm). J. Pharm. Pharmacology, 56, 677-81. http://dx.doi.org/10.1097/01.psy.0000132877.72833.71

Larrando, J. V., Agut, M., \& Calvo-Torras, M. A. (1995). Antimicrobial activity of essences from labiates. Microbios, 82, 171-72.

Mencherini, T., Picerno, P., Scesa, C., \& Aquino, R. (2007). Triterpene, antioxidant and antimicrobial compounds from Melissa officinalis. J. Nat. Prod., 70, 1889-94. http://dx.doi.org/10.1021/np070351s

Mulkens, A., \& Kapetanidis, I. (1988). Eugenylglucoside, a new natural phenylpropanoid heteroside from Melissa officinalis. J. Nat. Prod., 51, 496-98. http://dx.doi.org/10.1021/np50057a006

Schultze, W., Hose, S., Abou-Mandour, A., \& Czygan, F. C. (1993). Melissa officinalis L. (Lemon balm) in vitro culture and the production and analysis of volatile compounds. In Y. P. S. Bajaj (Ed.), Biotechnology in Agriculture and Forestry (Vol. 24, pp. 242-68). Berlin: Springer-Verlag. https://doi.org/10.1007/978-3-642 $-58062-8 \_18$

Selvamangai, C., \& Bhaskar, A. (2012). GC-MS Analysis of Phytocomponents in the Methanolic Extract of Eupatorium triplinerve. Inter. J. Drug Dev. \& Res., 4(4), 148-53.

Stalling, D. L., Gehrke, C. W., \& Zumwalt, R. W. (1968). A new silylation reagent for amino acids bis(trimethylsilyl)trifluoroacetamide (BSTFA). Biochem. Biophy. Res. Comm., 31(4), 616-22.

Tagashira, M., \& Ohtake, Y. (1998). A New antioxidative 1, 3-benzodioxole from Melissa officinalis. Planta. Med., 64, 555-8. http://dx.doi.org/10.1055/s-2006-957513

Vitullo, M., Ripabelli, I., Fanelli, I., Tamburro, M., Delfine, S., \& Sammarco, L. (2011). Microbiological and toxicological quality of dried herbs. Lett. Appl. Microbiol., 52, 573-80. http://dx.doi.org/10.1111/j.1472765X.2011.03040.X

Yamasaki, K., Nakano, M., Kawahata, T., Mori, H., Otake, T., \& Ueba, N. (1998). Anti HIV-1 activity of herbs in Labiatae. Biol. Pharm. Bull., 21, 829-33.

Ziakova, A., \& Brandsteterova, E. (2003). Validation of HPLC determination of phenolic acids present in some Lamiaceae family plants. J. Liquid Chromatogr., 26, 443-53. https://doi.org/10.1081/JLC-120017181

\section{Copyrights}

Copyright for this article is retained by the author(s), with first publication rights granted to the journal.

This is an open-access article distributed under the terms and conditions of the Creative Commons Attribution license (http://creativecommons.org/licenses/by/4.0/). 